\title{
Benchmarks
}

Received 27 July 2000; accepted 27 November 2000.

\author{
Margaret Byrne, Bronwyn \\ Macdonald, and \\ Michael Francki ${ }^{1}$ \\ Department of Conservation \\ and Land Management \\ Bentley Delivery Centre \\ 'The University of Western \\ Australia \\ Crawley, WA, Australia
}

\section{Use of Inexpensive Dyes to Calibrate and Adjust Your Microarray Printer}

\section{BioTechniques 30:748 (April 2001)}

A critical factor in the preparation of cDNA microarrays is the calibration and adjustment of the array printer to optimize spotting. Here are a couple techniques to help you detect the quality of your print, the proper calibration, and the condition of your printing pins. A simple way to determine the quality of the array spots is to examine the salt deposits remaining after the droplet of printer material has dried. However, this method does not necessarily reflect the morphology of the nucleic acid on the array because of the drying effects. Another common method includes the use of free $\mathrm{Cy}^{\circledR} 3-\mathrm{dCTP} / \mathrm{dUTP}$ or $\mathrm{Cy}{ }^{\circledR} 5$ dCTP/dUTP dyes (Amersham Pharmacia Biotech, Piscataway, NJ, USA) or dyes containing oligonucleotides, followed by fluorescence scanning (1). Here, we describe an inexpensive alternative to using expensive fluorescent probes for the calibration and adjustment of pin-type array printers.

Using a Stanford cDNA microarray printer (http://cmgm.stanford.edu/pbrown/ mguide/index.html) with ChipMaker ${ }^{\mathrm{TM}} 3$ spotting pins (TeleChem International, Sunnyvale, CA, USA), we compared the results of printing under two conditions, with and without DNA. The goal of the calibration and adjustment steps is to ob-

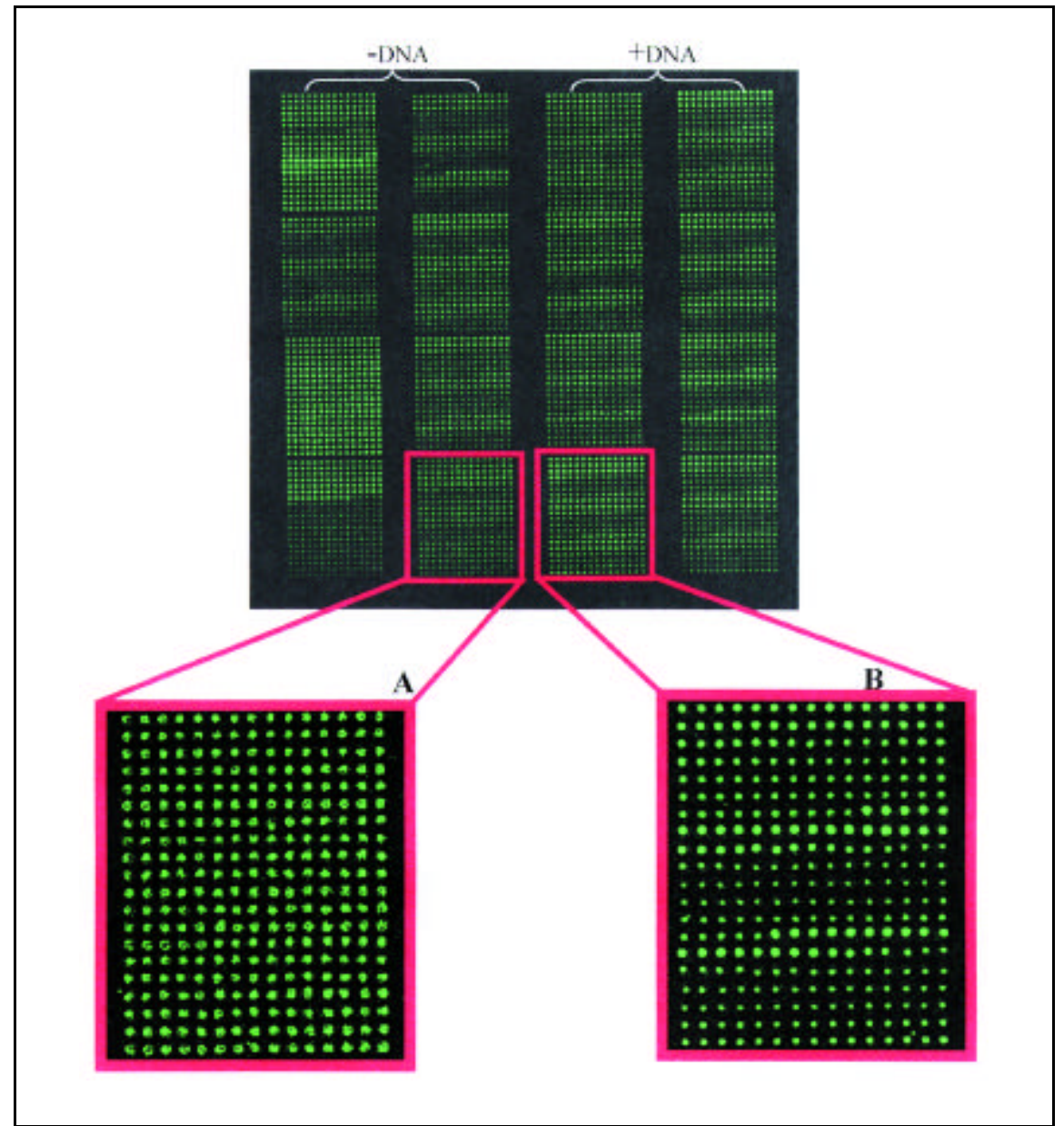

Figure 1. Salt deposition \pm DNA (at $0.25 \mathrm{mg} / \mathrm{mL}$ ). (A) Zoomed area printed without DNA. (B) Zoomed area printed with $0.25 \mathrm{mg} / \mathrm{mL}$ of sheared Salmon sperm DNA. Spots in panel B seem to be more uniform due to additional viscosity from DNA.

tain uniform and consistent spots. We used plain red and blue food coloring dye in 1:1000 dilution of $3 \times$ standard saline citrate (SSC) with sheared salmon sperm DNA at $0.25 \mathrm{mg} / \mathrm{mL}$ to mimic the actual printing conditions. All fluorescent scans were performed on a Packard/GSI Lumonics 3000 scanner (GSI Lumonics, Northville, MI, USA), with $85 \%$ laser and $90 \%$ PMT settings (Figure 1). The quality of the DNA spots was further examined with DNA binding dyes (data not shown).

In the future, with the help of food coloring dye, we are going to compare different types of printing buffers such as $50 \%$ dimethyl sulfoxide (DMSO) with and without DNA, formamide, and a new printing buffer that recently became available from Mosaic Technologies (Waltham, MA, USA) and Clontech Laboratories (Palo Alto, CA, USA).

\section{REFERENCES}

1.Hegde, P., R. Qi, K. Abernathy, C. Gay, S. Dharap, R. Gaspard, J.E. Hughes, E. Snesrud et al. 2000. A concise guide to cDNA microarray analysis. BioTechniques 29:548-562.

Address correspondence to Gregory Khitrov, Director of Gene Array Facility, The Rockefeller University Gene Array Facility, 1230 York Ave., Box 203, New York, NY 10021, USA. e-mail: khitrog@ rockefeller.edu

Received 17 October 2000; accepted 27 November 2000.

Gregory Khitrov

Rockefeller University

New York, NY, USA 